\title{
Inflammation, immune suppression, and tumor progression
}

\author{
Suzanne Ostrand-Rosenberg \\ From São Paulo Advanced School of Comparative Oncology \\ Águas de São Pedro, Brazil. 30 September - 6 October 2012
}

The tumor microenvironment is a complex milieu of tumor and host cells. Host cells can include tumor-reactive $\mathrm{T}$ cells capable of killing tumor cells. However, more frequently tumor and host components interact to generate a highly immune suppressive environment that frustrates $\mathrm{T}$ cell cytotoxicity and promotes tumor progression through a variety of immune and non-immune mechanisms. Myeloid-derived suppressor cells (MDSC) are a major host component contributing to the immune suppressive environment. MDSC accumulate in most patients and experimental mice with cancer. They inhibit both adaptive and innate immunity through a diverse array of suppressive mechanisms and therefore are a significant obstacle for natural immunity and for active cancer immunotherapies. Their accumulation and suppressive potency are driven by pro-inflammatory mediators. In addition to their inherent immune suppressive function, MDSC amplify the immune suppressive activity of macrophages and dendritic cells via cross-talk which results in the up-regulation of inflammatory mediators. Cross-talk between MDSC and other myeloid cells is itself enhanced by inflammation, resulting in an autocrine tumor microenvironment that sustains and amplifies immune suppression. This talk will describe the cell-cell interactions used by MDSC to inhibit anti-tumor immunity and promote tumor progression, and the role of inflammation in promoting cross-talk between MDSC and other cells in the tumor microenvironment.

\section{Competing interests}

There are no competing interests in this presentation.

\section{Acknowledgements}

Supported by NIH R01CA84232; RO1CA115880.

Correspondence: srosenbe@umbc.edu

University of Maryland Baltimore County, Dept. Biological Sciences, Baltimore, MD 21250, USA
Published: 4 April 2013

doi:10.1186/1753-6561-7-S2-K20

Cite this article as: Ostrand-Rosenberg: Inflammation, immune suppression, and tumor progression. BMC Proceedings 2013 7(Suppl 2): K20.
Submit your next manuscript to BioMed Central and take full advantage of:

- Convenient online submission

- Thorough peer review

- No space constraints or color figure charges

- Immediate publication on acceptance

- Inclusion in PubMed, CAS, Scopus and Google Scholar

- Research which is freely available for redistribution
C Biomed Central
C Biomed Central

(c) 2013 Ostrand-Rosenberg; licensee BioMed Central Ltd. This is an Open Access article distributed under the terms of the Creative Commons Attribution License (http://creativecommons.org/licenses/by/2.0), which permits unrestricted use, distribution, and reproduction in any medium, provided the original work is properly cited. 